\title{
ANALISIS PERHITUNGAN HARGA POKOK PRODUKSI MENGGUNAKAN METODE VARIABLE COSTING PADA PT. CELEBES MINAPRATAMA BITUNG
}

\author{
Dewi Sartika Kiay \\ Jenny Morasa \\ Winston Pontoh
}

\author{
Fakultas Ekonomi dan Bisnis Jurusan Akuntansi \\ Universitas Sam Ratulangi Manado \\ email: dedew_thika@yahoo.co.id
}

\begin{abstract}
ABSTRAK
Harga Pokok Produksi merupakan kumpulan dari biaya-biaya yang dikeluarkan untuk mengolah bahan baku menjadi bahan jadi. Penelitian ini bertujuan untuk mengetahui analisis perhitungan harga pokok produksi pengolahan ikan kayu pada PT. Celebes Minapratam Bitung. Perusahaan ini merupakan perusahaan manufaktur yang juga tidak luput dari masalah perhitungan biaya produksi dan dalam menentukan harga pokok produksi perusahaan menggunakan metode biaya penuh dimana pemisahan unsur biaya produksi yang bersifat variable dan tetap belum dilakukan. Hal ini mengakibatkan ketidaktepatan dalam perhitungan harga pokok produk yang akan berpengaruh terhadap penetapan harga jual dan laba perusahaan. Analisis data penlelitian ini yaitu, proses produksi, laporan biaya bahan, laporan biaya tenaga kerja, laporan biaya overhead. Hasil penelitian penentuan harga pokok produksi menggunakan metode dimana biaya dihitung berdasarkan metode biaya penuh ada baiknya perhitungan yang digunakan menurut metode variable costing. Perhitungan ini menghasilkan selisih yang berpengaruh terhadap penetapan harga jual. Untuk itu perusahaan hendaknya memisahkan biaya produksi sehingga menghasilkan biaya produksi yang tepat.
\end{abstract}

Kata kunci : harga pokok produksi, variable costing

\section{ABSTRACT}

Cost of Production is a collection of the costs incurred to process raw materials into finished materials. This study aims to determine the analytical calculation of the cost of production of fish processing wood at PT . Celebes Minapratam Bitung. This company is a manufacturing company was not immune from the problem and the calculation of production costs in determining the cost of production companies using the full cost method of separating elements where production costs are variable and fixed yet done. This has led to inaccuracies in the calculation of the cost of the product will affect the determination of the selling price and profit. The data analysis penlelitian ie, production processes, material cost report, report labor costs, overhead cost report. The results of determining the cost of production using the method in which the cost is calculated based on the full cost method is better according to the method of calculation used variable costing. This results in differences that affect the determination of the selling price. For that the company should separate the production costs resulting in proper production costs .

Keywords : cost of production, variable costing 


\section{PENDAHULUAN}

\section{Latar Belakang}

Perusahaan sebagai badan usaha mempunyai beberapa bentuk tujuan. Tujuan-tujuan tersebut berdasarkan perencanaan yang telah disusun sebelumnya dalam perusahaan. Diantara tujuan tersebut yang terpenting adalah mendapatkan laba optimum. Hal ini dimaksudkan untuk menunjang kelangsungan hidup dan perluasan usaha. Bagi perusahaan industri, informasi mengenai biaya produksi merupakan salah satu jenis infromasi yang penting. Informasi ini dapat digunakan untuk berbagai tujuan, seperti pengendalian biaya demi tercapainya efisiensi, penentuan harga jual produk, pengambilan keputusankeputusan khusus seperti apakah suatu produk akan tetap diproduksi atau apakah suatu produk akan dibeli dari luar ataupun diproduksi sendiri oleh perusahaan, serta berbagai tujuan lainnya. Dalam menghitung harga pokok produksi, perlu dijelaskan terlebih dahulu pengertian dan perbedaan metode full costing dan variabel costing. Metode full costing adalah salah satu metode penentuan biaya produk yang membebankan seluruh biaya produksi sebagai biaya produk, baik biaya produksi yang berperilaku tetap maupun yang berperilaku variabel. Perusahaan yang menggunakan metode ini, menghitung harga pokok produksinya dengan menjumlahkan biaya bahan baku, biaya tenaga kerja langsung, biaya overhead pabrik variabel dan biaya overhead pabrik tetap. Perusahaan hendaknya mampu menetapkan harga pokok produksi yang tepat sehingga nantinya dapat bersaing dengan perusahaan lain yang sejenis.

\section{Tujuan Penelitian}

Penelitian ini bertujuan untuk menganalisis perhitungan harga pokok produksi menggunakan metode variable costing pada PT. Celebes Minapratama Bitung.

\section{TINJAUAN PUSTAKA}

\section{Konsep Akuntasi}

Secara umum, akuntansi (accounting) dapat diartikan sebagai sistem informasi yang menyediakan laporan untuk para pemangku kepentingan mengenai aktivitas ekonomi dan kondisi perusahaan. (Reeve 2009:9).

\section{Sistem Akuntansi}

Sistem akuntansi mencatat kejadian serta transaksi ekonomi, seperti penjualan dan pembelian bahan, dan memroses data dalam transaksi tersebut menjadi informasi yang berguna bagi maanjer, tenaga penjual, penyelia produksi, dan pihak lainnya. Pemrosesan setiap transaksi ekonomi meliputi pengumpulan (collecting), pengategorian (categorizing), peringkasan (summarizing), dan penganalisisan (analyzing). Sistem akuntansi menyajikan informasi yang ditemukan dalam laporan rugi-laba, neraca, serta laporan arus kas dan dalam laporan kinerja, seperti biaya operasi suatu pabrik atau biaya pemberian jasa. (Hongren 2008:2).

\section{Pengertian Harga Pokok Produksi}

Harga pokok produksi Mulyadi ( 2007:10) merupakan pengorbanan sumber ekonomi yang diukur dalam satuan uang yang telah terjadi atau kemungkinan terjadi untuk memperoleh penghasilan. Harga pokok produksi (cost of goods manufactured) adalah jumlah biaya produksi yang diserap oleh seluruh produk jadi yang telah selesai diproduksi selama satu periode tertentu. Marbun (2003: 91). Harga pokok produksi adalah kumpulan biaya produksi yang terdiri dari bahan baku langsung, tenaga kerja langsung, 
dan biaya overhead pabrik ditambah persediaan produk dalam proses awal dan dikurang persediaan produk dalam proses akhir Bustami dkk (2006: 60). Sedangkan menurut Supriyono (2011: 144) harga pokok produksi adalah aktiva atau jasa yang dikorbankan atau diserahkan dalam proses produksi yang meliputi biaya bahan baku, biaya tenaga kerja, biaya overhead pabrik dan termasuk biaya produksi.

\section{Metode Penentuan Harga Pokok Produksi}

Metode penentuan harga pokok produksi adalah cara memperhitungkan unsur-unsur biaya ke dalam harga pokok produksi. Dalam memperhitungkan unsur biaya ini, terdapat dua pendekatan yaitu:

1.Full costing

Mulyadi (2009:17) full costing merupakan metode penentuan kos produksi yang terdiri dari biaya bahan baku, biaya tenaga kerja langsung, dan biaya overhead pabrik, baik yang berperilaku variabel maupun tetap. Dapat dikatakan bahwa metode full costing merupakan metode penentuan harga pokok yang memasukan biaya overhead pabrik baik yang berperilaku tetap maupun variabel, dibebankan kepada produk yang diproduksi atas dasar tarif yang ditentukan di muka pada biaya overhead sesungguhnya.

\section{Variabel costing}

Variabel costing merupakan metode penentuan kos produksi yanghanya memperhitungkan biaya produksi yang berperilaku variabel ke dalam kos produksi, yang terdiri dari biaya bahan baku, biaya tenaga kerja langsung dan biaya overhead pabrik variable. Mulyadi (2009:18).

\section{Penelitian Terdahulu}

Sebagai bahan referensi dan rujukan terhadap analisis hasil penelitian ini, maka diperlukan beberapa peneliti terdahulu diantaranya terlampir dalam tabel 1 dibawah ini: 
Tabel 1. Penelitian Terdahulu

\begin{tabular}{|c|c|c|c|c|c|c|}
\hline $\begin{array}{c}\text { Nama } \\
\text { Peneliti/ } \\
\text { Tahun } \\
\end{array}$ & Judul & Tujuan & $\begin{array}{c}\text { Metode } \\
\text { Penelitian }\end{array}$ & $\begin{array}{c}\text { Hasil } \\
\text { Penelitian }\end{array}$ & Persamaan & Perbedaan \\
\hline $\begin{array}{l}\text { Sihombing } \\
(2003)\end{array}$ & $\begin{array}{l}\text { Penerapan metode } \\
\text { variable costing } \\
\text { dalam perhitungan } \\
\text { harga pokok } \\
\text { produksi pada PT. } \\
\text { Mututama Agung } \\
\text { Lestari Medan }\end{array}$ & $\begin{array}{c}\text { Untuk } \\
\text { melihat dan } \\
\text { menilai } \\
\text { apakah } \\
\text { terdapat } \\
\text { kesesuain } \\
\text { antara teori } \\
\text { dan praktek }\end{array}$ & $\begin{array}{l}\text { Deskripftif } \\
\text { Kuantitatif }\end{array}$ & $\begin{array}{c}\text { Penelitian } \\
\text { ini } \\
\text { diharapkan } \\
\text { dapat } \\
\text { memberikan } \\
\text { gambaran } \\
\text { mengenai } \\
\text { penentuan } \\
\text { harga pokok } \\
\text { produksi } \\
\text { yang benar }\end{array}$ & $\begin{array}{c}\text { Penelitian } \\
\text { dengan } \\
\text { menggunaka } \\
\text { n metode } \\
\text { variable } \\
\text { costing untuk } \\
\text { menghitung } \\
\text { harga pokok } \\
\text { produksi }\end{array}$ & $\begin{array}{c}\text { Penelitian ini } \\
\text { melihat sejauh } \\
\text { mana penerapan } \\
\text { metode variable } \\
\text { costing yang telah } \\
\text { digunakan oleh } \\
\text { perusahaan dalam } \\
\text { menghitung harga } \\
\text { pokok produksi } \\
\text { sedangkan } \\
\text { penelitian } \\
\text { selanjutnya } \\
\text { menganalisa } \\
\text { metode perusahaan } \\
\text { kemudian dianalisa } \\
\text { kembali sesuai } \\
\text { metode variable } \\
\text { costing }\end{array}$ \\
\hline $\begin{array}{l}\text { Sihite } \\
(2012)\end{array}$ & $\begin{array}{c}\text { Analisis } \\
\text { penentuan harga } \\
\text { pokok produksi } \\
\text { pada perusahaan } \\
\text { garam beryodium } \\
\text { studi kasus pada } \\
\text { UD. Empat } \\
\text { Mutiara }\end{array}$ & $\begin{array}{c}\text { Untuk } \\
\text { melihat } \\
\text { bagaimana } \\
\text { penentuan } \\
\text { harga pokok } \\
\text { produksi } \\
\text { dalam } \\
\text { perusahaan }\end{array}$ & Kuantitatif & $\begin{array}{c}\text { Dapat } \\
\text { diketahui } \\
\text { penentuan } \\
\text { harga pokok } \\
\text { produksi } \\
\text { dalam } \\
\text { perusahaan }\end{array}$ & $\begin{array}{c}\text { Untuk } \\
\text { menghitung } \\
\text { harga pokok } \\
\text { produksi } \\
\text { tentunya } \\
\text { dibutuhkan } \\
\text { informasi } \\
\text { mengenai } \\
\text { biaya bahan } \\
\text { baku, tenaga } \\
\text { kerja dan } \\
\text { overhead } \\
\text { pabrik }\end{array}$ & $\begin{array}{c}\text { Penelitian ini } \\
\text { menghitung harga } \\
\text { pokok produksi } \\
\text { tanpa } \\
\text { memanfaatkan } \\
\text { metode full costing } \\
\text { atau variable } \\
\text { costing sedangkan } \\
\text { penelitian } \\
\text { selanjutnya secara } \\
\text { lebih spesifik } \\
\text { menghitung harga } \\
\text { pokok produksi } \\
\text { sesuai dengan } \\
\text { metode variable } \\
\text { costing }\end{array}$ \\
\hline
\end{tabular}

Sumber: Sihombing (2003) dan Sihite (2012).

\section{METODE PENELITIAN}

\section{Jenis Penelitian}

Jenis peneltian ini bersifat deskriptif kuantitatif, yaitu penggambaran tentang objek penelitian yang dilihat dari sumber atau informasi keuangan berupa, laporan biaya produksi PT. Celebes Minapratama dan informasi mengenai gambaran umum perusahaan. Penelitian ini merupakan penelitian Komparatif. Dimana dalam penelitian ini ingin membandingkan nilai harga pokok produksi yang paling efisien menggunakan metode perhitungan full costing atau menggunakan metode perhitungan variable costing. 


\section{Tempat dan Waktu Penelitian}

Penelitian ini dilakukan diperusahaan manufaktur pengolahan ikan kemasan yaitu PT. Celebes Minapratama yang terletak di kota bitung provinsi sulawesi utara. Waktu penelitian dilaksanakan pada hari/tanggal, kamis 11 april tahun 2013. Dengan menggunakan analisa berdasarkan metode analisis data deskriptif dengan mengumpulkan data-data sesuai dengan sebenarnya kemudian data tersebut disusun, diolah dan dianalisis untuk dapat memberikan gambaran mengenai masalah yang ada.

Penelitian dengan metode analisis deskriptif ini mengukur antara toeri pendukung dengan hasil senyatanya yang ada dalam perusahaan. Dalam hal ini yang berkaitan dengan harga pokok produksi pengolahan ikan di PT. Celebes Minapratama Bitung.

\section{Populasi dan Sampel}

Populasi adalah semua nilai baik hasil perhitugan maupun pengukuran, baik kuantitatif maupun kualitatif, dari pada karakteristik tertentu mengenai sekelompok obyek yang lengkap dan jelas. Adapun populasi dalam penelitian ini adalah laporan biaya produksi PT. Celebes Minapratama Bitung. Sampel adalah suatu himpunan bagian (subset) dari unit populasi. Adapun sampel dalam yang digunakan adalah laporan biaya produksi PT Celebes Minapratama Bitung di tahun 2011.

\section{Metode Pengumpulan Data}

Metode penelitian dengan cara mengumpulkan data-data sesuai dengan yang sebenarnya kemudian data-data tersebut disusun, diolah dan dianalisis untuk dapat memberikan gambaran mengenai masalah yang ada.

\section{Metode Analisis}

Analisis data dalam penelitian ini menggunakan metode deskriptif karena penelitian ini bertujuan untuk mendeskripsikan perbandingan nilai harga pokok produksi apabila menggunakan metode full costing dan variable costing serta melihat manakah di antara kedua metode tersebut yang paling efektif digunakan.

\section{HASIL PENELITIAN DAN PEMBAHASAN}

\section{Gambaran Umum Perusahaan}

PT. Celebes Minapratama merupakan salah satu perusahaan yang bergerak dibidang perikanan (pengolahan ikan kayu/arahon bushi atau dalam bahasa inggrisnya dried smoke fish) yang terdapat di bitung, Sulawesi utara. Sejarah berdirinya adalah sebagai berikut: pada akhir tahun 1999, bapak Albert O. Worang yang pada saat itu menjabat direktur utama PT. Manado Mina Citrataruna melihat bahwa pengolahan ikan kayu sangat laris dipasarkan bahkan niat pembeli khususnya dari jepang sangat banyak. Dengan melihat peluang yang sangat besar ini, muncul ide untuk melakukan pengembangan usaha pada bidang pengolahan ikan kayu sekalipun keadaan perekonomian pada waktu itu tidak begitu menguntungkan bagi eksportir, bahkan persaingan semakin ketat.

Tetapi karena keinginan yang sangat besar untuk melakukan perluasan usaha, maka pada akhir tahun 1999, bapak Albert O. Worang menyerahkan jabatannya sebagai direktur utama PT. Manado mina Citrataruna dan langsung mendirikan perusahaan yang beru bersama-sama dengan bapak Kornelius Kilapong, bapak Jefry Pangkerego (keduanya eks staf PT, Manado mina Citrataruna) dan ibu Rine Kaunang. Pendirian perusahaan ini berdasarkan akte notaris nomor 76 tanggal 24 oktober 2000. 


\section{Hasil Penelitian}

\section{Hasil Produksi}

PT. Celebes Minapratama merupakan industri pengolah ikan (arabushi), hasil produksinya diekspor ke jepang. Kapasitas produksi sekitar 30 ton per hari. Perusahaan ini selama sebulan bekerja selama 22 hari.

\section{Informasi Biaya}

Biaya produksi merupakan biaya-biaya yang terjadi untuk mengolah bahan baku yaitu ikan segar menjadi produk jadi berupa ikan olahan yang telah dikemas dan siap untuk dijual. Pada umumnya biaya produksi dibedakan menjadi biaya bahan baku, biaya tenaga kerja dan biaya overhead pabrik. Biaya bahan baku dan biaya tenaga kerja langsung disebut biaya utama, sedangkan biaya tenaga kerja tidak langsung dan biaya overhead pabrik disebut biaya konversi. Pada PT. Celebes Minapratama Bitung, biaya bahan baku, biaya tenaga kerja langsung, dan biaya overhead pabrik digolongkan sebagai biaya produksi.Perhitungan harga pokok produksi ikan olahan yang telah dilakukan perusahaan selama ini menggunakan metode full costing. Dimana biaya-biaya yang diperhitungkan dlam penetapan harga pokok produksi meliputi biaya bahan baku, biaya tenaga kerja langsung da biaya overhead pabrik. Perhitungan biaya-biaya produksi terlampir pada tabel 2 dibawah ini:

\section{Biaya bahan}

Tabel 2. Biaya Bahan

\begin{tabular}{lcc}
\hline \multicolumn{1}{c}{ Keterangan } & \multicolumn{1}{c}{ Total } \\
\hline Persediaan awal & $\mathrm{Rp}$ & $1,514,477,371$ Sumbe \\
Masuk/pembelian & $\mathrm{Rp}$ & $29,787,858,720$ \\
Persediaan yang tersedia untuk dipakai & $\mathrm{Rp}$ & $31,302,336,091$ \\
Persediaan Akhir & $\mathrm{Rp}$ & $1,152,980,663$ \\
Harga pokok bahan yang dipakai & $\mathrm{Rp}$ & $30,149,355,428$ \\
\hline
\end{tabular}

Sumber: PT. Celebes Minapratama Bitung (2011)

Berdasarkan perhitungan biaya bahan maka jumlah biaya bahan yang digunakan untuk untuk produksi untuk di ahun 2011 adalah Rp. 30,149,355,428

2. Biaya Tenaga Kerja Langsung

biaya tenaga kerja langsung merupakan biaya yang dikeluarkan untuk membayar upah, thr, pesangon, tunjangan kesehatan dan pajak penghasilan. Berikut ini akan dilampirkan pada tebel 3 di bawah ini:

Tabel 3. Biaya Tenaga Kerja Langsung

\begin{tabular}{|c|c|c|}
\hline Keterangan & & Total \\
\hline Upah & $\mathrm{Rp}$ & $2,210,089,330$ \\
\hline THR & $\mathrm{Rp}$ & $106,325,001$ \\
\hline Pesangon & $\mathrm{Rp}$ & $330,892,500$ \\
\hline Jamsostek perusahaan & $\mathrm{Rp}$ & $123,834,109$ \\
\hline Jamsostek pribadi & $\mathrm{Rp}$ & $23,830,700$ \\
\hline pph 21 & $\mathrm{Rp}$ & $18,856,431$ \\
\hline JUMLAH & $\mathbf{R p}$ & $2,813,828,071$ \\
\hline
\end{tabular}

Sumber: PT. Celebes Sumber Minapratama Bitung (2011) 
Berdasarkan perhitungan maka jumlah biaya tenaga kerja langsung sesuai yang dikategorikan oleh perusahaan sebanyak Rp. 2,813,828,071

1. Biaya Overhead Pabrik

PT. Celebes Minapratama Bitung membebankan biaya overhead pada

produk berdasarkan biaya yang sesungguhnya terjadi, baik biaya yang terjadi di pabrik maupun kantor. Berikut akan dilampirkan pada tabel 4 dibawah ini:

Tabel 4. Biaya Overhead Pabrik

\begin{tabular}{llr}
\hline \multicolumn{1}{c}{ Keterangan } & & \multicolumn{1}{c}{ Total } \\
\hline Solar & $\mathrm{Rp}$ & $1,594,548,724$ \\
Kayu Bakar & $\mathrm{Rp}$ & $629,133,703$ \\
Dos Packing & $\mathrm{Rp}$ & $244,343,033$ \\
Plastik produk 26\% & $\mathrm{Rp}$ & $11,092,200$ \\
Kawat loket & $\mathrm{Rp}$ & $9,000,000$ \\
Oxygen absorber & $\mathrm{Rp}$ & $75,944,550$ \\
Tenaga kerja tak langsung & $\mathrm{Rp}$ & $521,115,186$ \\
Listrik & $\mathrm{Rp}$ & $275,898,380$ \\
Bengkel/Reparasi & $\mathrm{Rp}$ & $37,125,500$ \\
Penyusutan bangunan pabrik & $\mathrm{Rp}$ & $23,303,100$ \\
Penyusutan rehab bangunan pabrik & $\mathrm{Rp}$ & $24,563,270$ \\
Penyusutan mesin produksi & $\mathrm{Rp}$ & $480,197,230$ \\
penyusutan gudang kayu & $\mathrm{Rp}$ & $4,405,804$ \\
PBB Pabrik (bangunan) & $\mathrm{Rp}$ & $7,232,200$ \\
pph BBM & $\mathrm{Rp}$ & $4,620,750$ \\
Sanksi Adm & $\mathrm{Rp}$ & $51,659,815$ \\
pph pasal 23 & $\mathrm{Rp}$ & 258,000 \\
Penyusutan bangunan slice \& fish meal & $\mathrm{Rp}$ & $98,100,125$ \\
Penyusutan Rehab bangunan slice meal & $\mathrm{Rp}$ & $5,063,035$ \\
Asuransi & $\mathrm{Rp}$ & $8,597,717$ \\
Penyusutan rehab gudang kayu & $\mathrm{Rp}$ & $1,863,350$ \\
Ekspedisi & $\mathrm{Rp}$ & $281,061,365$ \\
Kontainer export & $\mathrm{Rp}$ & $1,699,444,710$ \\
Perlengkapan/Peralatan produksi & $\mathrm{Rp}$ & $259,885,259$ \\
Bahan bakar/bhn Pembantu & $\mathrm{Rp}$ & $329,529,555$ \\
Biaya lain-lain & $\mathrm{Rp}$ & $10,048,000$ \\
& $\mathrm{Rp}$ & $\mathbf{6 , 6 8 8 , 0 3 4 , 5 6 1}$ \\
\hline SwmbH & &
\end{tabular}

Sumber: PT. Celebes Minapratama Bitung (2011)

Berdasarkan laporan biaya produksi PT. Celebes Minapratama Bitung yang sudah dihitung dengan jumlah ikan olahan yang dihasilkan, maka dapat dihitung harga pokok produksi ikan olahan di tahun 2011 dengan metode perusahaan yaitu metode full costing adalah sebagai berikut.

Biaya bahan

Biaya tenaga kerja langsung

Biaya overhead pabrik

Total harga pokok produksi

Total produksi

Harga pokok produksi per unit
$\mathrm{Rp} \quad 30,149,355,428$

$\mathrm{Rp} \quad 2,813,828,071$

Rp $\quad 6,688,034,561$

Rp $\quad 39,651,218,060$

900,000
$\mathrm{Rp} \quad 44,057$


Berdasarkan perhitungan diatas diperoleh harga pokok produksi untuk setiap kilogram ikan olahan adalah Rp. 44,057.

\section{Pembahasan}

Mulyadi (2012: 121) mengungkapkan full costing dan variable costing sesungguhnya merupakan metode penentuan harga pokok produksi. Perbedaan pokok yang ada di antara kedua metode tersebut adalah terletak pada perlakuan terhadap biaya produksi yang berperilaku tetap. Adanya perbedaan perlakuan terhadap biaya produksi tetap ini akan mempunyai akibat pada perhitungan harga pokok produksi dan penyajian laporan laba rugi. Perhitungan harga pokok produksi dengan menggunakan metode perusahaan yaitu full costing belum dapat dikatakan akurat dalam menghitung harga pokok produksi dikarenkan dalam metode yang dipakai perusahaan dihitung undur biaya yang bersifat tetap dan variabel. Dan dalam pembahasan nantinya penulis akan menghitung unsur-unsur biaya produksi berdasarkan metode variable costing, dimana tidak semua unsur-unsur biaya produksi yang dimasukkan akan menjadi hasil dari perhitungan harga pokok produksi tetapi hanya unsur biaya produksi yang bersifat variabel saja yang akan digunakan sebagai dasar pembentukan harga pokok produksi.

\section{Biaya Bahan}

Untuk menghitung biaya bahan atau harga pokok bahan adalah sebagai berikut.

$\begin{array}{llr}\text { Persediaan awal } & \text { Rp } & 1,514,477,371 \\ \text { Masuk/pembelian } & \text { Rp } & \underline{29,787,858,720} \\ \text { Persediaan yang tersedia untuk dipakai } & \text { Rp } & 31,302,336,091 \\ \text { Persediaan Akhir } & \text { Rp } & \underline{1,152,980,663} \\ \text { Harga pokok bahan yang dipakai } & \text { Rp } & 30,149,355,428\end{array}$

\section{Biaya Tenaga Kerja}

Dari pengelompokkan biaya khususnya untuk tenaga kerja langsung maka yang akan dihitung nantinya biaya upah langsung di tahun 2011 yaitu sebesar Rp. 2,813.828,071

\section{Biaya overhead pabrik}

PT. Celebes Minapratama bitung membebankan biaya overhead pada produk berdasarkan biaya yang sesungguhnya terjadi, baik biaya yang terjadi dipabrik maupun kantor. Namun penelitian ini akan mengalokasikan biaya overhead pabrik ke produk yang memiliki biaya overhead variabel, dikarenakan biaya overhead variabel dialokasikan berdasarkan satuan unit produksi melihat karena perushaan memproduksi satu jenis produk saja. 
Tabel 5. Biaya Overhead Pabrik

\begin{tabular}{|c|c|c|c|c|c|c|}
\hline Keterangan & & Tetap & & Variabel & & Total \\
\hline Solar & $\mathrm{Rp}$ & $128,840.00$ & $\mathrm{Rp}$ & $1,594,677,564.00$ & $\mathrm{Rp}$ & $1,594,806,404.00$ \\
\hline Kayu Bakar & $\mathrm{Rp}$ & $16,297.00$ & $\mathrm{Rp}$ & $629,150,000.00$ & $\mathrm{Rp}$ & $629,166,297.00$ \\
\hline Dos Packing & $\mathrm{Rp}$ & $6,967.00$ & $\mathrm{Rp}$ & $244,350,000.00$ & $\mathrm{Rp}$ & $244,356,967.00$ \\
\hline Plastik produk $26 \%$ & $\mathrm{Rp}$ & $7,800.00$ & $\mathrm{Rp}$ & $11,100,000.00$ & $\mathrm{Rp}$ & $11,107,800.00$ \\
\hline Kawat loket & $\mathrm{Rp}$ & - & $\mathrm{Rp}$ & $9,000,000.00$ & $\mathrm{Rp}$ & $9,000,000.00$ \\
\hline Oxygen absorber & $\mathrm{Rp}$ & $5,450.00$ & $\mathrm{Rp}$ & $75,950,000.00$ & $\mathrm{Rp}$ & $75,955,450.00$ \\
\hline Tenaga kerja tak langsung & $\mathrm{Rp}$ & 15,186 & $\mathrm{Rp}$ & $521,100,000.00$ & $\mathrm{Rp}$ & $521,115,186.00$ \\
\hline Listrik & & $1,620.00$ & $\mathrm{Rp}$ & $275,900,000.00$ & $\mathrm{Rp}$ & $275,901,620.00$ \\
\hline Bengkel/Reparasi & $\mathrm{Rp}$ & $24,500.00$ & $\mathrm{Rp}$ & $37,150,000.00$ & $\mathrm{Rp}$ & $37,174,500.00$ \\
\hline Penyusutan bangunan pabrik & $\mathrm{Rp}$ & $23,303,100.00$ & $\mathrm{Rp}$ & - & $\mathrm{Rp}$ & $23,303,100.00$ \\
\hline Penyusutan rehab bangunan pabrik & $\mathrm{Rp}$ & $24,563,270.00$ & $\mathrm{Rp}$ & - & $\mathrm{Rp}$ & $24,563,270.00$ \\
\hline Penyusutan mesin produksi & $\mathrm{Rp}$ & $480,197,230.00$ & $\mathrm{Rp}$ & - & $\mathrm{Rp}$ & $480,197,230.00$ \\
\hline penyusutan gudang kayu & $\mathrm{Rp}$ & $4,405,804.00$ & $\mathrm{Rp}$ & - & $\mathrm{Rp}$ & $4,405,804.00$ \\
\hline PBB Pabrik (bangunan) & $\mathrm{Rp}$ & $7,232,200.00$ & $\mathrm{Rp}$ & - & $\mathrm{Rp}$ & $7,232,200.00$ \\
\hline pph BBM & $\mathrm{Rp}$ & $4,620,750.00$ & $\mathrm{Rp}$ & - & $\mathrm{Rp}$ & $4,620,750.00$ \\
\hline Sanksi Adm & $\mathrm{Rp}$ & $51,659,815.00$ & $\mathrm{Rp}$ & - & $\mathrm{Rp}$ & $51,659,815.00$ \\
\hline pph pasal 23 & $\mathrm{Rp}$ & $258,000.00$ & $\mathrm{Rp}$ & - & $\mathrm{Rp}$ & $258,000.00$ \\
\hline Penyusutan bangunan slice $\&$ fish meal & $\mathrm{Rp}$ & $98,100,125.00$ & $\mathrm{Rp}$ & - & $\mathrm{Rp}$ & $98,100,125.00$ \\
\hline Penyusutan Rehab bangunan slice meal & $\mathrm{Rp}$ & $5,063,035.00$ & $\mathrm{Rp}$ & - & $\mathrm{Rp}$ & $5,063,035.00$ \\
\hline Asuransi & $\mathrm{Rp}$ & $8,597,717.00$ & $\mathrm{Rp}$ & - & $\mathrm{Rp}$ & $8,597,717.00$ \\
\hline Penyusutan rehab gudang kayu & $\mathrm{Rp}$ & $1,863,350.00$ & $\mathrm{Rp}$ & - & $\mathrm{Rp}$ & $1,863,350.00$ \\
\hline Ekspedisi & $\mathrm{Rp}$ & $281,061,365.00$ & $\mathrm{Rp}$ & - & $\mathrm{Rp}$ & $281,061,365.00$ \\
\hline Kontainer export & $\mathrm{Rp}$ & $1,699,444,710.00$ & $\mathrm{Rp}$ & - & $\mathrm{Rp}$ & $1,699,444,710.00$ \\
\hline Perlengkapan/Peralatan produksi & $\mathrm{Rp}$ & $14,983.00$ & $\mathrm{Rp}$ & $259,900,000.00$ & $\mathrm{Rp}$ & $259,914,983.00$ \\
\hline Bahan bakar/bhn Pembantu & $\mathrm{Rp}$ & $32,529,555.00$ & $\mathrm{Rp}$ & - & $\mathrm{Rp}$ & $32,529,555.00$ \\
\hline Biaya lain-lain & $\mathrm{Rp}$ & $10,048,000.00$ & $\mathrm{Rp}$ & - & $\mathrm{Rp}$ & $10,048,000.00$ \\
\hline Jumlah & $\mathbf{R p}$ & $2,733,169,669.00$ & Rp3 & $658,277,564.00$ & $\mathbf{R p}$ & ,391,447,233.00 \\
\hline
\end{tabular}

Sumber: Data diolah tahun 2013

Berdasarkan hasil perhitungan di atas, maka dapat dihitung harga pokok produksi PT. Celebes Minapratama berdasarkan metode variable costing seperti yang terdapat di bawah ini.

Biaya bahan

Biaya tenaga kerja langsung

Biaya overhead pabrik variabel

Total harga pokok produksi

Total produksi (unit)

Harga pokok produksi (Unit)

\begin{tabular}{rr} 
Rp & $30,149,355,428.00$ \\
Rp & $2,813,828,071.00$ \\
Rp & $3,658,277,564.00$ \\
Rp & $36,621,461,063.00$ \\
& $900,000.00$ \\
\hline Rp & $40,690.51$
\end{tabular}

Berdasarkan perhitungan harga pokok produksi di atas maka di dapat hasil perbandingan harga pokok produksi per unit antara yang diperoleh dari PT. Celebes Minapratama dengan hasil pembahasan. Perbandingan dapat dilihat sebagai berikut. 
Tabel 6. Perbandingan Harga Pokok Produksi

\begin{tabular}{llllc}
\hline $\begin{array}{l}\text { Keterangan } \\
\text { Hasil yang } \\
\text { diperoleh }\end{array}$ & \multicolumn{2}{c}{ Metode Perushaan (Full Costing) } & \multicolumn{2}{c}{ Metode Variable Costing } \\
\hline Selisih & $\mathrm{Rp}$ & $44,057.00$ & $\mathrm{Rp}$ & $40,690.51$ \\
\hline Sum & & $\mathrm{Rp}$ & $3,366.49$ \\
\hline
\end{tabular}

Sumber: Data diolah tahun 2013

Berdasarkan table 6 dapat dilihat bahwa terdapat perbedaan antara metode yang digunakan perusahaan dengan metode yang dipakai peneliti yaitu metode variable costing. Perhitungan dengan menggunakan metode perusahaan (full costing) menghasilkan harga pokok yang lebih besar, sedangkan metode variable costing menghasilkan harga pokok produksi yang lebih kecil dikarenakan variable costing menelusuri biaya-biaya yang berkaitan langsung dengan proses produksi yang sifatnya variabel atau berubah seiring dengan perubahan volume kegiatan produksi. Perhitungan dengan metode variable costing akan berguna bagi perusahaan untuk melakukan efisiensi sumber daya yang digunakan dalam kegiatan produksi di PT. Celebes Minapratama dan untuk penetapan harga jual sesuai dengan keuntungan yang diharapkan perusahaan.

\section{Kesimpulan}

\section{PENUTUP}

Berdasarkan penelitian yang dilakukan pada PT. Celebes Minaprtama Bitung mengenai analisis perhitungan biaya produksi dengan menggunakan metode perusahaan yang dapat disimpulkan sebagai berikut.

1. Perbedaan antara full costing dan variable costing.

Full costing merupakan metode penentuan harga pokok produksi yang memperhitung akan semua unsu biaya produksi kedalam harga pokok produksi yang terdiri dari biaya bahan baku, biaya tenaga kerja langsung, dan biaya overhead pabrik baik yang berperilaku tetap maupun yang berperilaku variabel. Sedangkan variable costing meruapakan metode penentuan harga pokok produksi yang hanya memperhitungkan biaya produksi yang berperilaku variable kedalam harga pokok produksi yang terdiri dari biaya bahan baku, biaya tenaga kerja langsung dan biaya overhead pabrik variabel.

2. Perhitungan biaya pada perusahaan masih belum memadai karena belum dibuatnya laporan perhitungan biaya produksi untuk metode variable costing.

3. Perusahaan dalam menghitung biaya produksinya menggunakan system biaya sesungguhnya dan bukan system biaya standar, sehingga perusahaan tidak dapat mengadakan analisa biaya variable dalam hal pengawasan biaya untuk dapat menilai efisiensi serta penyimpangan-penyimpangan yang terjadi dalam proses produksi.

4. Perusahaan mengalami kesulitan dalam memisahkan unsur-unsur biaya tetap dan biaya variable dari biaya yang tergolong semi-variabel. Hal ini tentunya menyulitkan perusahaan dalam mencari hubungan antara biaya-biaya tersebut.

\section{Saran}

Agar PT. Celebes Minapratama Bitung dalam menentukan harga pokok produksinya dapat lebih tepat dan lebih teliti maka penulis memberikan saran sebagai berikut.

1. Perusahaan sebaiknya memakai metode variable costing dalam menghitung harga pokok produksi, karena metode variable costing memperhitungkan biaya-biaya yang langsung berkaitan dengan produk yang di produksi, sedangkan metode full costing menghitung biaya overhead variable dan biaya overhead tetap 
2. Perusahaan hendaknya dapat menentukan harga pokok produksi yang lebih ekonomis dengan melakukan kegiatan produksi secara lebih optimal, sehingga harga jual yang dicapai perusahaan bisa bersaing dengan perusahaan lain yang memproduksi produk sejenis di pasaran.

\section{DAFTAR PUSTAKA}

Bustami., Bastian., Nurlela., 2006. Akuntansi Biaya, Teori dan Aplikasi, Edisi Pertama. Graha Ilmiah. Yogyakarta.

Hongren. 2008. Akuntansi Biaya: Penekanan Manajerial. Jilid 1. PT. INDEKS. Jakarta.

Sihite, Lundur Bontor 2012. Analisis Penentuan Harga Pokok Produksi pada Perusahaan Garam Beryodium Studi pada UD. Empat Mutiara. Jurnal (Volume 1, Nomor 1). Universitas Sumatera Utara. Medan. http://ejournal-s1.undip.ac.id/index.php/accounting/issue/view/3. (10 desember 2012).

Marbun,B.N. 2003. Kamus Manajemen, Cetakan I. Pusaka Sinar Harapan. Jakarta.

Mulyadi. 2007. Sistem Akuntansi. Salemba Empat. Jakarta.

Mulyadi. 2009. Akuntansi Biaya. Aditya Media. Yogyakarta.

Mulyadi. 2012. Akuntansi Biaya. Unit penerbit dan percetakan Sekolah Tinggi Ilmu Manajemen YKPN. Yogyakarta.

Reeve. 2009. Pengantar Akuntansi: Adaptasi Indonesia. Buku 1. Salemba Empat: Jakarta

Sihombing, Posma. 2003. Penerapan Metode Variable Costing dalam Perhitungan Harga Pokok Produksi pada PT. Mututama Agung Lestari Medan. Skripsi (karya ilmiah) Universitas Negeri Medan. Medan._www.tuugo.net/Companies/mututama-agung-lestari-pt/0160001044786 $(10$ desember 2012).

Supriyono, R. A. 2011. Akuntansi Biaya. BPFE. Yogyakarta. 